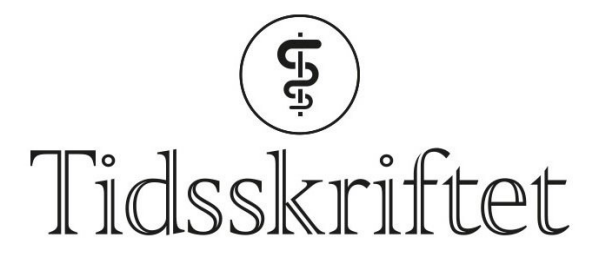

DEN NORSKE LEGEFORENING

\title{
Stressykdom øker risiko for autoimmun sykdom
}

FRA ANDRE TIDSSKRIFTER

PETTER MORTEN PETTERSEN

Tidsskriftet

Stressrelaterte lidelser gir økt risiko for senere utvikling av autoimmun sykdom. Dette viser en svensk studie.

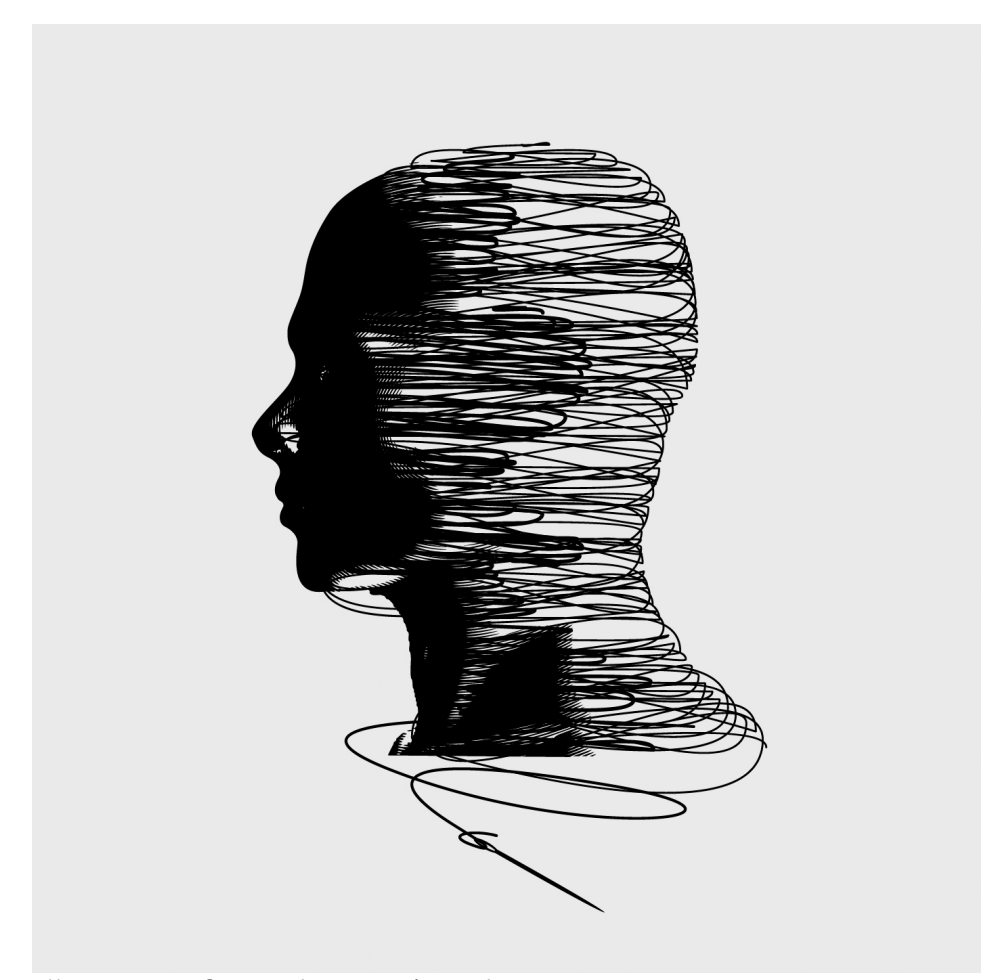

Illustrasjonsfoto: solarseven/iStock.

Den svenske kohortstudien omfattet alle personer som hadde vært registrert med stressrelaterte lidelser i det nasjonale pasientregisteret i perioden 1981-2013, til sammen rundt 125 ooo personer (1). Lidelsene ble kategorisert som posttraumatisk stresslidelse, akutt stressreaksjon og tilpasningsforstyrrelse og andre stressreaksjoner. I løpet av en median oppfølgingstid på ti år var insidensraten for autoimmun sykdom 9,1 per 1 ooo personår for gruppen som hadde hatt stressrelaterte lidelser, mot 6,o og 6,5 per personår i henholdsvis bakgrunnsbefolkningen og blant søsken. Det tilsvarer en absolutt risikodifferanse på 3,12 ( $95 \%$ KI 2,99-3,25) og 2,49 (2,23-2,76).

- Vi vet at traumer og stress påvirker immunforsvaret og dermed mottagelighet for 
sykdommer, sier Ted Reichborn-Kjennerud, som er psykiater, epidemiolog og avdelingsdirektør ved Divisjon for psykisk helse i Folkehelseinstituttet. - Denne studien gir oss nye funn, og det er ikke mange epidemiologiske studier som har vist en slik sammenheng. Studiens store populasjonsbaserte utvalg og sammenligning med søsken gir studien særlig styrke. Hvorvidt behandling av stressrelaterte sykdommer vil senke risikoen for autoimmune sykdommer, er usikkert, men dersom dette bekreftes i andre studier, vil dette gjøre det enda viktigere å behandle stressrelaterte sykdommer, sier ReichbornKjennerud.

\section{LITTERATUR:}

1. Song H, Fang F, Tomasson G et al. Association of stress-related disorders with subsequent autoimmune disease. JAMA 2018; 319: 2388 - 400. [PubMed][CrossRef]

Publisert: 15. oktober 2018. Tidsskr Nor Legeforen. DOI: 10.4045/tidsskr.18.0637

(C) Tidsskrift for Den norske legeforening 2020. Lastet ned fra tidsskriftet.no 